6-1998

\title{
Postimpact deformation associated with the late Eocene Chesapeake Bay impact structure in southeastern Virginia
}

Gerald H. Johnson

Department of Geology

Sarah E. Kruse

Allison W. Vaughn

Department of Geology

John K. Lucey

Department of Geology

C. Hobbs

Virginia Institute of Marine Science

See next page for additional authors

Follow this and additional works at: https://scholarworks.wm.edu/vimsarticles

Part of the Geology Commons

\section{Recommended Citation}

Johnson, Gerald H.; Kruse, Sarah E.; Vaughn, Allison W.; Lucey, John K.; Hobbs, C.; and Powars, David S., Postimpact deformation associated with the late Eocene Chesapeake Bay impact structure in southeastern Virginia (1998). Geology (Boulder), 26(6), 507-510.

DOI:10.1130/0091-7613(1998)026 2.3.C0;2

This Article is brought to you for free and open access by the Virginia Institute of Marine Science at W\&M ScholarWorks. It has been accepted for inclusion in VIMS Articles by an authorized administrator of W\&M ScholarWorks. For more information, please contact scholarworks@wm.edu. 


\section{Authors}

Gerald H. Johnson, Sarah E. Kruse, Allison W. Vaughn, John K. Lucey, C. Hobbs, and David S. Powars 


\title{
Postimpact deformation associated with the late Eocene Chesapeake Bay impact structure in southeastern Virginia
}

\author{
Gerald H. Johnson \\ Department of Geology, College of William and Mary, Williamsburg, Virginia 23187 \\ Sarah E. Kruse \\ Department of Geology, University of South Florida, Tampa, Florida 33620 \\ Allison W. Vaughn \\ John K. Lucey \\ Department of Geology, College of William and Mary, Williamsburg, Virginia 23187 \\ Carl H. Hobbs III \\ Virginia Institute of Marine Science, Gloucester Point, Virginia 23062 \\ David S. Powars \\ Water Resources Division, U.S. Geological Survey, Baltimore, Maryland 21237
}

\begin{abstract}
Upper Cenozoic strata covering the Chesapeake Bay impact structure in southeastern Virginia record intermittent differential movement around its buried rim. Miocene strata in a graben detected by seismic surveys on the York River exhibit variable thickness and are deformed above the crater rim. Fan-like interformational and intraformational angular unconformities within Pliocene-Pleistocene strata, which strike parallel to the crater rim and dip $2^{\circ}-3^{\circ}$ away from the crater center, indicate that deformation and deposition were synchronous. Concentric, large-scale crossbedded, bioclastic sand bodies of Pliocene age within $\sim 20 \mathrm{~km}$ of the buried crater rim formed on offshore shoals, presumably as subsiding listric slump blocks rotated near the crater rim.
\end{abstract}

\section{INTRODUCTION}

At large buried impact structures on the Yucatan Peninsula of Mexico and in the lower Chesapeake Bay region, crater topography and postimpact deformation significantly influenced late Cenozoic sedimentation and structure. Despite burial by 300-1000 m of Cenozoic carbonate sediments, the circumferential ring structure of the Cretaceous-Tertiary Chicxulub crater is reflected in the present landscape, including a ring of sinkholes overlying the outer rim (e.g., Perry et al., 1995; Pope et al., 1996; Morgan et al., 1997).

At the late Eocene Chesapeake Bay impact site (Fig. 1A), the submarine crater bathymetry was muted by near instantaneous partial filling with impact debris and wash-back or resurge deposits (Poag, 1997). Postimpact strata over the crater generally dip gently inward and are offset by numerous normal faults, presumably in response to differential compaction of the thick crater fill (Poag, 1996, 1997). In southeastern Virginia, long-recognized but previously unexplained anomalous stratigraphic and structural features are present within Miocene and Pliocene strata. In this paper we review near-surface structures and facies changes in later Tertiary formations close to the outer rim faults of Poag et al. (1994) that strike parallel to the crater rim. We attribute these features to postimpact deformation caused by slump-block motion near the outer rim of the impact structure. Evidence for ongoing
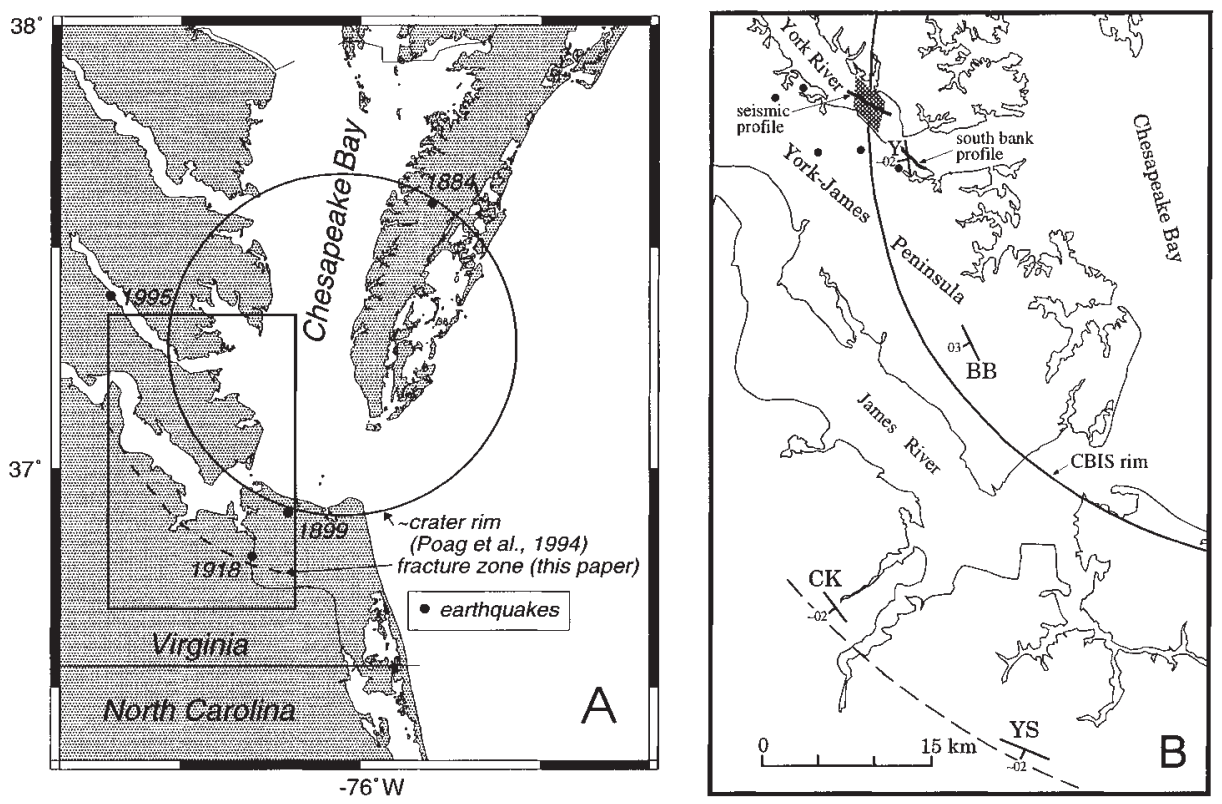

Figure 1. A: Approximate location of outer rim of Chesapeake Bay impact structure and epicenters of earthquakes from A.D. 1775 to present. Numbers indicate year earthquake occurred. 1995 earthquake (magnitude 2.6) occurred within $2 \mathrm{~km}$ (68\% probability) of location shown (Sibol et al., 1996); older earthquakes (unknown magnitude) within 10 to $20 \mathrm{~km}$ of locations shown (Martin Chapman, 1998, personal commun.). Magnitudes for the latter are unknown. Solid line is crater rim from Poag et al. (1994). Dashed line marks postulated location of secondary fault zone. B: Solid line is crater rim from Poag (1997). Thick line on south bank of York River shows location of cross section in Figure 3. Irregular line in York River marks location of seismic line in Figure 6. Solid circles mark locations of wells used in identification of reflectors in seismic line in Figure 6. Shaded region in York River shows graben imaged in seismic surveys. Dashed line marks postulated location of secondary fault zone. Strike and dip symbols show attitude of Pliocene-Pleistocene contact. Numbers indicate dip angle in degrees. $Y=$ Yorktown; BB = Big Bethel; CK = Chuckatuck; YS = Yadkins; CBIS = Chesapeake Bay impact structure. 
Figure 2. Generalized stratigraphic section for southeastern Virginia. Bold horizons are discussed in text.

\begin{tabular}{|c|c|}
\hline Quaternary & Pliocene-Pleistocene deposits \\
\hline \multirow[t]{2}{*}{ Pliocene } & Chowan River Formation \\
\hline & Yorktown Formation \\
\hline \multirow{2}{*}{ Miocene } & Eastover Formation \\
\hline & Lower Chesapeake Group formations \\
\hline Oligocene & Old Church Formation \\
\hline \multirow{2}{*}{ Eocene } & Chickahominy Formation \\
\hline & Exmore Breccia (late Eocene) \\
\hline Paleocene & Lower Pamunkey Group formations \\
\hline Cretaceous & Potomac Group \\
\hline \multicolumn{2}{|c|}{ Lower Mesozoic rift-basin deposits } \\
\hline Paleozoic & and Precambrian crystalline rocks \\
\hline
\end{tabular}

seismic deformation associated with the impact structure is ambiguous.

\section{REGIONAL SETTING}

The $~ 90-k m$-diameter Chesapeake Bay impact structure underlies the lower Chesapeake Bay region (Poag et al., 1994). The impactor penetrated Eocene to Cretaceous sediments and the underlying pre-Mesozoic crystalline rocks (Fig. 2) and created the water-saturated Exmore Breccia (Koeberl et al., 1996). This breccia, which contains abundant shock metamorphism, is $\sim 300 \mathrm{~m}$ thick in the annular trough (outer $\sim 30 \mathrm{~km}$ ) and thins rapidly to zero outside the outer rim (Koeberl et al., 1996; Poag, 1997). A zone of normal-faulted slump blocks is beneath the breccia pinchout, and faults displace Miocene and older strata (Poag, 1996). Postimpact strata drape over the outer rim and thicken toward the center of the crater, indicating ongoing crater subsidence during late Tertiary time (Poag, 1996).

Generally, Tertiary formations in southeastern Virginia are thin, tabular sheets of marine sand, silt, and shell debris that thicken and dip gently seaward. Along the outer rim of the impact structure these strata exhibit abrupt changes in thickness, lithology, and interformational and intraformational angular relationships, as observed in the Yadkins, Chuckatuck, and Big Bethel pits and in outcrop and subsurface on the York and James Rivers (Fig. 1B). Gentle folds in late Tertiary sediments have long been recognized on the lower coastal plain (Harris in Ward, 1993; Mansfield, 1943; Ward and Blackwelder, 1980), but their genesis has remained obscure.

\section{DATA}

To determine if the anomalous structures are aligned along the rim of the Chesapeake Bay impact structure we (1) made field observations of upper Miocene-Pliocene strata in southeastern Virginia, and (2) conducted shallow-marine seismic surveys along the York and James Rivers (Fig. 1B). These surveys, made in September 1996 aboard the R/V Langley of the Virginia Institute of Marine Science, utilized a Huntec "boomer-type" system at a $1 \mathrm{~s}$ repetition rate. Analog data were recorded with a single-channel, 5-m-long, 10 element "eel" and processed through a preamplifier and an ORE GeoPulse filter/amplifier with a $200-1500 \mathrm{~Hz}$ bandpass. Data were recorded on EPC-4800 and EPC-3200 graphic recorders to $250 \mathrm{~ms}$. Vibrations from traffic and construction precluded land seismic surveys near locations of anomalous structures on the York-James Peninsula.

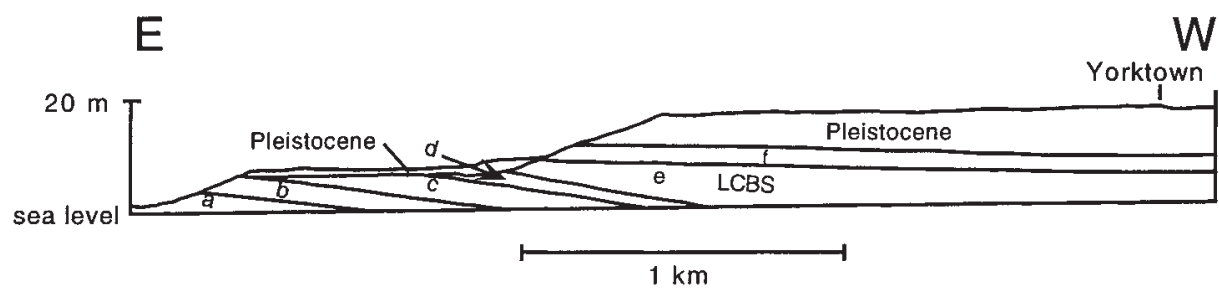

Figure 3. Cross section of bluffs along south bank of York River near Yorktown. Location shown with heavy line on south bank of York River near $Y$ in Figure 1B. Beds a-f are Yorktown Formation. Strata dip westward and are truncated by younger deposits. LCBS = large cross-bedded biofragmental sand body. Modified from Mansfield (1943).

\section{STRUCTURALANOMALIES}

Structural troughs, marked by reversals of regional dip, occur along the York and James Rivers. Along the south bank of the York River above Yorktown, Eastover, and Yorktown, strata $\operatorname{dip}(0.6 \mathrm{~m} / \mathrm{km})$ eastward; downstream the dip of these formations is reversed (Harris in Ward, 1993). The dip angle of upper Yorktown strata (beds a to f of Mansfield, 1943) (Fig. 3) exposed in the bluffs near Yorktown decreases progressively upward from $\sim 8.8 \mathrm{~m} / \mathrm{km}$ to $1.4 \mathrm{~m} / \mathrm{km}$, producing a fan-like effect. Bed e is a linear body of large-scale crossbedded biofragmental sand (Fig. 3). Angular unconformities separate bed f from older planar strata below and Pleistocene beds above.

A similar angular unconformity exists within upper Yorktown Formation beds in the Big Bethel pit (Fig. 4). In the northern and southeastern parts of the pit, the large cross-bedded biofragmental sand body rests directly on a Crepidula-bearing sand, and to the southwest it overlies inclined oyster shell-bearing sand and silicic-carbonate sand facies. The basal contact of the biofragmental sand body strikes $\mathrm{N} 23^{\circ} \mathrm{W}$ and dips $3^{\circ} \mathrm{SW}$. Pleistocene sediments rest with angular unconformity on the Yorktown Formation.

At the Yadkin pit, dipping planar-bedded, biofragmental sands of the Yorktown Formation are overlain with angular unconformity by fossiliferous sands of the upper Pliocene Chowan River Formation. Yorktown beds strike $\sim \mathrm{N} 65^{\circ} \mathrm{W}$ and dip south-southwest at more than $1^{\circ}$. The Chowan River Formation also dips to the southwest, and in the eastern and northern parts of the pit, it has been removed by Pleistocene erosion.

The westward and southwestward dips of the Yorktown and Chowan River strata, with dip angles decreasing upward in the sections, indicate that subsidence was accompanied by a pro-

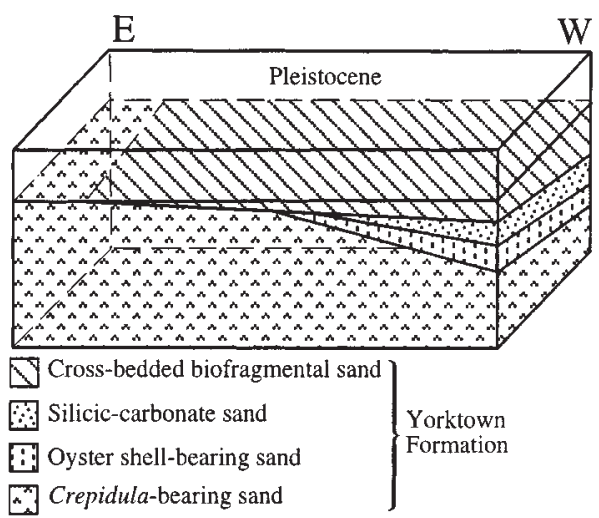

Figure 4. Schematic diagram of stratigraphic relationships within Yorktown Formation and overlying Pleistocene deposits at Big Bethel pit, Hampton, Virginia. West is to right for compatibility with Figure 3. Thickness of Yorktown strata shown schematically is $\sim 5 \mathrm{~m}$. Dip of base of oyster shell-bearing sand is $\sim 3^{\circ} \mathrm{SW}$. Location shown with BB in Figure 1B. 
gressive down-to-the-west and down-to-thesouthwest rotation of beds at these sites during late Pliocene time. Each structure clearly is incongruent with the general structural grain of coeval Coastal Plain strata, and each strikes roughly parallel to the crater rim (Fig. 1). These observations suggest that subsidence, through much of Pliocene time, at each of these sites was locally governed by ongoing slumping of fault blocks on either side of the outer rim of the Chesapeake Bay impact structure.

\section{STRATIGRAPHIC ANOMALIES}

Large bodies of westward-dipping, megacrossbedded biofragmental sands that intertongue landward with fine-grained lithofacies are present at Yorktown (Johnson, 1972) and at Chuckatuck (Johnson and Coch, 1969) (Fig. 1B). These bodies are lenticular in cross section, reach a maximum thickness of more than $20 \mathrm{~m}$, range in width from 1 to $2 \mathrm{~km}$ and in length from 3 to $6 \mathrm{~km}$, and are composed almost entirely of unlithified shell debris. The westward-dipping mega-cross-beds exceed $6 \mathrm{~m}$ in thickness and dip westward at angles of as much as $38^{\circ}$. The large, cross-bedded, biofragmental sand body at Yorktown trends north-south, and the sand body at Chuckatuck trends $\mathrm{N} 25^{\circ} \mathrm{W}$; both approximately parallel the crater rim. The uppermost beds of both biofragmental sand bodies dip outward from the crater center at $1^{\circ}-2^{\circ}$.

The composition, shape, and geographic distribution of the large cross-bedded biofragmental sand bodies, and their relationship to intertonguing sediments, require shoaling conditions seaward and a deeper basin landward (Fig. 5). As blocks near the crater wall slid along rim faults, the outer edges subsided and the inner margins were elevated, causing gentle folding of the overlying later Tertiary sediments and the formation of offshore shoals and landward basins. The large-scale cross-beds, fed by comminuted shell material generated on the shoal to the east, prograded outward into the basin. As the inner margin of the block was further elevated by continued rotation of the fault blocks, the older sediments were truncated by submarine scour (Fig. 5). This movement and subsequent erosion and deposition produced progressive truncation of older beds across individual slump blocks toward the crater. This deformation was ongoing because it created shoal-water conditions during the deposition of both the Yorktown and Chowan River formations.

\section{YORK RIVER STRUCTURES}

Shallow seismic surveys on the York River reveal a north-south-striking graben $\sim 1.5 \mathrm{~km}$ wide that overlies the seismically imaged boundary fault of Poag (1996) (Fig. 6) (Vaughn, 1997). The graben is present at two-way travel times of as low as $\sim 50 \mathrm{~ms}$. Thinned strata and pinchouts at 140 and 90 ms (A and B, Fig. 6) between draped
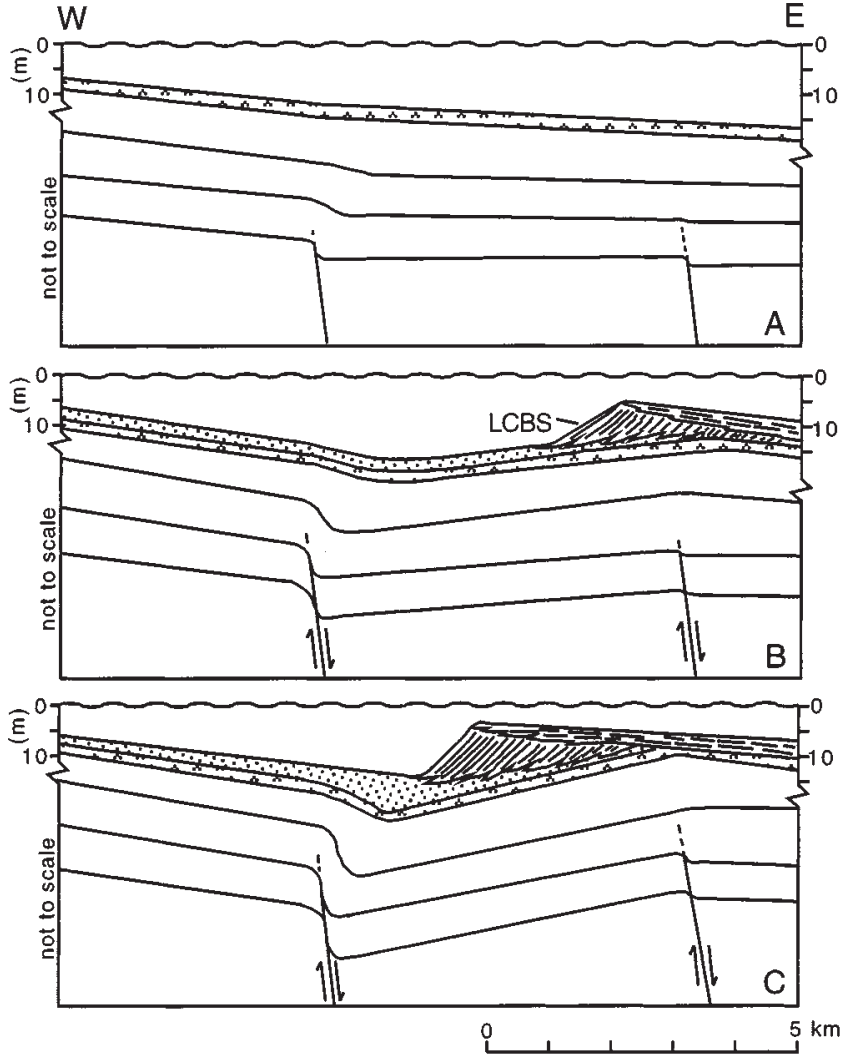
$\mathrm{km}$

F Planar bedded biofragmental sand

/// Cross-bedded biofragmental sand

Basinal silt, clay, fine sand

Basal transgressive shelly sand Older sediments
Yorktown Formation .
Figure 5 . Schematic show-
ing formation of large cross-
bedded biofragmental sand
bodies and basinal deposits
at Yorktown and Chucka-
tuck, locations shown with Y
and CK, respectively, in Fig-
ure $1 \mathrm{~B}$. A: Marine trans-
gression during period of
tectonic quiescence while
lower middle Yorktown was
deposited. B: Development
of basin and shoal and
deposition of accompanying
sediments in response to
rotation of underlying slump
blocks during deposition of
middle Yorktown Formation.
C: Growth and migration of
cross-bedded biofragmental
sand upward and eastward
across basinal sediments
during deposition of upper
Yorktown Formation.

Figure 5 . Schematic show-
ing formation of large cross-
bedded biofragmental sand
bodies and basinal deposits
at Yorktown and Chucka-
tuck, locations shown with Y
and CK, respectively, in Fig-
ure $1 \mathrm{~B}$. A: Marine trans-
gression during period of
tectonic quiescence while
lower middle Yorktown was
deposited. B: Development
of basin and shoal and
deposition of accompanying
sediments in response to
rotation of underlying slump
blocks during deposition of
middle Yorktown Formation.
C: Growth and migration of
cross-bedded biofragmental
sand upward and eastward
across basinal sediments
during deposition of upper
Yorktown Formation.

Figure 5 . Schematic show-
ing formation of large cross-
bedded biofragmental sand
bodies and basinal deposits
at Yorktown and Chucka-
tuck, locations shown with Y
and CK, respectively, in Fig-
ure $1 \mathrm{~B}$. A: Marine trans-
gression during period of
tectonic quiescence while
lower middle Yorktown was
deposited. B: Development
of basin and shoal and
deposition of accompanying
sediments in response to
rotation of underlying slump
blocks during deposition of
middle Yorktown Formation.
C: Growth and migration of
cross-bedded biofragmental
sand upward and eastward
across basinal sediments
during deposition of upper
Yorktown Formation.

Figure 5 . Schematic show-
ing formation of large cross-
bedded biofragmental sand
bodies and basinal deposits
at Yorktown and Chucka-
tuck, locations shown with Y
and CK, respectively, in Fig-
ure $1 \mathrm{~B}$. A: Marine trans-
gression during period of
tectonic quiescence while
lower middle Yorktown was
deposited. B: Development
of basin and shoal and
deposition of accompanying
sediments in response to
rotation of underlying slump
blocks during deposition of
middle Yorktown Formation.
C: Growth and migration of
cross-bedded biofragmental
sand upward and eastward
across basinal sediments
during deposition of upper
Yorktown Formation.

Figure 5 . Schematic show-
ing formation of large cross-
bedded biofragmental sand
bodies and basinal deposits
at Yorktown and Chucka-
tuck, locations shown with Y
and CK, respectively, in Fig-
ure $1 \mathrm{~B}$. A: Marine trans-
gression during period of
tectonic quiescence while
lower middle Yorktown was
deposited. B: Development
of basin and shoal and
deposition of accompanying
sediments in response to
rotation of underlying slump
blocks during deposition of
middle Yorktown Formation.
C: Growth and migration of
cross-bedded biofragmental
sand upward and eastward
across basinal sediments
during deposition of upper
Yorktown Formation.

Figure 5 . Schematic show-
ing formation of large cross-
bedded biofragmental sand
bodies and basinal deposits
at Yorktown and Chucka-
tuck, locations shown with Y
and CK, respectively, in Fig-
ure $1 \mathrm{~B}$. A: Marine trans-
gression during period of
tectonic quiescence while
lower middle Yorktown was
deposited. B: Development
of basin and shoal and
deposition of accompanying
sediments in response to
rotation of underlying slump
blocks during deposition of
middle Yorktown Formation.
C: Growth and migration of
cross-bedded biofragmental
sand upward and eastward
across basinal sediments
during deposition of upper
Yorktown Formation.

Figure 5 . Schematic show-
ing formation of large cross-
bedded biofragmental sand
bodies and basinal deposits
at Yorktown and Chucka-
tuck, locations shown with Y
and CK, respectively, in Fig-
ure $1 \mathrm{~B}$. A: Marine trans-
gression during period of
tectonic quiescence while
lower middle Yorktown was
deposited. B: Development
of basin and shoal and
deposition of accompanying
sediments in response to
rotation of underlying slump
blocks during deposition of
middle Yorktown Formation.
C: Growth and migration of
cross-bedded biofragmental
sand upward and eastward
across basinal sediments
during deposition of upper
Yorktown Formation.

Figure 5 . Schematic show-
ing formation of large cross-
bedded biofragmental sand
bodies and basinal deposits
at Yorktown and Chucka-
tuck, locations shown with Y
and CK, respectively, in Fig-
ure $1 \mathrm{~B}$. A: Marine trans-
gression during period of
tectonic quiescence while
lower middle Yorktown was
deposited. B: Development
of basin and shoal and
deposition of accompanying
sediments in response to
rotation of underlying slump
blocks during deposition of
middle Yorktown Formation.
C: Growth and migration of
cross-bedded biofragmental
sand upward and eastward
across basinal sediments
during deposition of upper
Yorktown Formation.

Figure 5 . Schematic show-
ing formation of large cross-
bedded biofragmental sand
bodies and basinal deposits
at Yorktown and Chucka-
tuck, locations shown with Y
and CK, respectively, in Fig-
ure $1 \mathrm{~B}$. A: Marine trans-
gression during period of
tectonic quiescence while
lower middle Yorktown was
deposited. B: Development
of basin and shoal and
deposition of accompanying
sediments in response to
rotation of underlying slump
blocks during deposition of
middle Yorktown Formation.
C: Growth and migration of
cross-bedded biofragmental
sand upward and eastward
across basinal sediments
during deposition of upper
Yorktown Formation.

Figure 5 . Schematic show-
ing formation of large cross-
bedded biofragmental sand
bodies and basinal deposits
at Yorktown and Chucka-
tuck, locations shown with Y
and CK, respectively, in Fig-
ure $1 \mathrm{~B}$. A: Marine trans-
gression during period of
tectonic quiescence while
lower middle Yorktown was
deposited. B: Development
of basin and shoal and
deposition of accompanying
sediments in response to
rotation of underlying slump
blocks during deposition of
middle Yorktown Formation.
C: Growth and migration of
cross-bedded biofragmental
sand upward and eastward
across basinal sediments
during deposition of upper
Yorktown Formation.

Figure 5 . Schematic show-
ing formation of large cross-
bedded biofragmental sand
bodies and basinal deposits
at Yorktown and Chucka-
tuck, locations shown with Y
and CK, respectively, in Fig-
ure $1 \mathrm{~B}$. A: Marine trans-
gression during period of
tectonic quiescence while
lower middle Yorktown was
deposited. B: Development
of basin and shoal and
deposition of accompanying
sediments in response to
rotation of underlying slump
blocks during deposition of
middle Yorktown Formation.
C: Growth and migration of
cross-bedded biofragmental
sand upward and eastward
across basinal sediments
during deposition of upper
Yorktown Formation.

Figure 5 . Schematic show-
ing formation of large cross-
bedded biofragmental sand
bodies and basinal deposits
at Yorktown and Chucka-
tuck, locations shown with Y
and CK, respectively, in Fig-
ure $1 \mathrm{~B}$. A: Marine trans-
gression during period of
tectonic quiescence while
lower middle Yorktown was
deposited. B: Development
of basin and shoal and
deposition of accompanying
sediments in response to
rotation of underlying slump
blocks during deposition of
middle Yorktown Formation.
C: Growth and migration of
cross-bedded biofragmental
sand upward and eastward
across basinal sediments
during deposition of upper
Yorktown Formation.

Figure 5 . Schematic show-
ing formation of large cross-
bedded biofragmental sand
bodies and basinal deposits
at Yorktown and Chucka-
tuck, locations shown with Y
and CK, respectively, in Fig-
ure $1 \mathrm{~B}$. A: Marine trans-
gression during period of
tectonic quiescence while
lower middle Yorktown was
deposited. B: Development
of basin and shoal and
deposition of accompanying
sediments in response to
rotation of underlying slump
blocks during deposition of
middle Yorktown Formation.
C: Growth and migration of
cross-bedded biofragmental
sand upward and eastward
across basinal sediments
during deposition of upper
Yorktown Formation.

Figure 5 . Schematic show-
ing formation of large cross-
bedded biofragmental sand
bodies and basinal deposits
at Yorktown and Chucka-
tuck, locations shown with Y
and CK, respectively, in Fig-
ure $1 \mathrm{~B}$. A: Marine trans-
gression during period of
tectonic quiescence while
lower middle Yorktown was
deposited. B: Development
of basin and shoal and
deposition of accompanying
sediments in response to
rotation of underlying slump
blocks during deposition of
middle Yorktown Formation.
C: Growth and migration of
cross-bedded biofragmental
sand upward and eastward
across basinal sediments
during deposition of upper
Yorktown Formation.

Figure 5 . Schematic show-
ing formation of large cross-
bedded biofragmental sand
bodies and basinal deposits
at Yorktown and Chucka-
tuck, locations shown with Y
and CK, respectively, in Fig-
ure $1 \mathrm{~B}$. A: Marine trans-
gression during period of
tectonic quiescence while
lower middle Yorktown was
deposited. B: Development
of basin and shoal and
deposition of accompanying
sediments in response to
rotation of underlying slump
blocks during deposition of
middle Yorktown Formation.
C: Growth and migration of
cross-bedded biofragmental
sand upward and eastward
across basinal sediments
during deposition of upper
Yorktown Formation.

Figure 5 . Schematic show-
ing formation of large cross-
bedded biofragmental sand
bodies and basinal deposits
at Yorktown and Chucka-
tuck, locations shown with Y
and CK, respectively, in Fig-
ure $1 \mathrm{~B}$. A: Marine trans-
gression during period of
tectonic quiescence while
lower middle Yorktown was
deposited. B: Development
of basin and shoal and
deposition of accompanying
sediments in response to
rotation of underlying slump
blocks during deposition of
middle Yorktown Formation.
C: Growth and migration of
cross-bedded biofragmental
sand upward and eastward
across basinal sediments
during deposition of upper
Yorktown Formation.

Figure 5 . Schematic show-
ing formation of large cross-
bedded biofragmental sand
bodies and basinal deposits
at Yorktown and Chucka-
tuck, locations shown with Y
and CK, respectively, in Fig-
ure $1 \mathrm{~B}$. A: Marine trans-
gression during period of
tectonic quiescence while
lower middle Yorktown was
deposited. B: Development
of basin and shoal and
deposition of accompanying
sediments in response to
rotation of underlying slump
blocks during deposition of
middle Yorktown Formation.
C: Growth and migration of
cross-bedded biofragmental
sand upward and eastward
across basinal sediments
during deposition of upper
Yorktown Formation.

Figure 5 . Schematic show-
ing formation of large cross-
bedded biofragmental sand
bodies and basinal deposits
at Yorktown and Chucka-
tuck, locations shown with Y
and CK, respectively, in Fig-
ure $1 \mathrm{~B}$. A: Marine trans-
gression during period of
tectonic quiescence while
lower middle Yorktown was
deposited. B: Development
of basin and shoal and
deposition of accompanying
sediments in response to
rotation of underlying slump
blocks during deposition of
middle Yorktown Formation.
C: Growth and migration of
cross-bedded biofragmental
sand upward and eastward
across basinal sediments
during deposition of upper
Yorktown Formation.

Figure 5 . Schematic show-
ing formation of large cross-
bedded biofragmental sand
bodies and basinal deposits
at Yorktown and Chucka-
tuck, locations shown with Y
and CK, respectively, in Fig-
ure $1 \mathrm{~B}$. A: Marine trans-
gression during period of
tectonic quiescence while
lower middle Yorktown was
deposited. B: Development
of basin and shoal and
deposition of accompanying
sediments in response to
rotation of underlying slump
blocks during deposition of
middle Yorktown Formation.
C: Growth and migration of
cross-bedded biofragmental
sand upward and eastward
across basinal sediments
during deposition of upper
Yorktown Formation.

Figure 5 . Schematic show-
ing formation of large cross-
bedded biofragmental sand
bodies and basinal deposits
at Yorktown and Chucka-
tuck, locations shown with Y
and CK, respectively, in Fig-
ure $1 \mathrm{~B}$. A: Marine trans-
gression during period of
tectonic quiescence while
lower middle Yorktown was
deposited. B: Development
of basin and shoal and
deposition of accompanying
sediments in response to
rotation of underlying slump
blocks during deposition of
middle Yorktown Formation.
C: Growth and migration of
cross-bedded biofragmental
sand upward and eastward
across basinal sediments
during deposition of upper
Yorktown Formation.

Figure 5 . Schematic show-
ing formation of large cross-
bedded biofragmental sand
bodies and basinal deposits
at Yorktown and Chucka-
tuck, locations shown with Y
and CK, respectively, in Fig-
ure $1 \mathrm{~B}$. A: Marine trans-
gression during period of
tectonic quiescence while
lower middle Yorktown was
deposited. B: Development
of basin and shoal and
deposition of accompanying
sediments in response to
rotation of underlying slump
blocks during deposition of
middle Yorktown Formation.
C: Growth and migration of
cross-bedded biofragmental
sand upward and eastward
across basinal sediments
during deposition of upper
Yorktown Formation.

Figure 5 . Schematic show-
ing formation of large cross-
bedded biofragmental sand
bodies and basinal deposits
at Yorktown and Chucka-
tuck, locations shown with Y
and CK, respectively, in Fig-
ure $1 \mathrm{~B}$. A: Marine trans-
gression during period of
tectonic quiescence while
lower middle Yorktown was
deposited. B: Development
of basin and shoal and
deposition of accompanying
sediments in response to
rotation of underlying slump
blocks during deposition of
middle Yorktown Formation.
C: Growth and migration of
cross-bedded biofragmental
sand upward and eastward
across basinal sediments
during deposition of upper
Yorktown Formation.

Figure 5 . Schematic show-
ing formation of large cross-
bedded biofragmental sand
bodies and basinal deposits
at Yorktown and Chucka-
tuck, locations shown with Y
and CK, respectively, in Fig-
ure $1 \mathrm{~B}$. A: Marine trans-
gression during period of
tectonic quiescence while
lower middle Yorktown was
deposited. B: Development
of basin and shoal and
deposition of accompanying
sediments in response to
rotation of underlying slump
blocks during deposition of
middle Yorktown Formation.
C: Growth and migration of
cross-bedded biofragmental
sand upward and eastward
across basinal sediments
during deposition of upper
Yorktown Formation.

Figure 5 . Schematic show-
ing formation of large cross-
bedded biofragmental sand
bodies and basinal deposits
at Yorktown and Chucka-
tuck, locations shown with Y
and CK, respectively, in Fig-
ure $1 \mathrm{~B}$. A: Marine trans-
gression during period of
tectonic quiescence while
lower middle Yorktown was
deposited. B: Development
of basin and shoal and
deposition of accompanying
sediments in response to
rotation of underlying slump
blocks during deposition of
middle Yorktown Formation.
C: Growth and migration of
cross-bedded biofragmental
sand upward and eastward
across basinal sediments
during deposition of upper
Yorktown Formation.

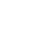


layers of relatively uniform thickness suggest that graben subsidence in Miocene time was intermittent (little graben subsidence relative to surroundings during deposition of uniformly thick layers), the most recent event postdating upper Miocene reflectors (C, Fig. 6). These structures suggest that the outer rim continued to serve as a focus of deformation through the Miocene. Complex shallow structures ( $<30 \mathrm{~ms}$, Fig. 6) preclude interpretation of younger deformation.

\section{SEISMICITY}

The four reported earthquakes in southeastern Virginia (Sibol et al., 1996, 1997) (Fig. 1A) occurred less than $40 \mathrm{~km}$ from the outer rim of Poag et al. (1994). Although this spatial coincidence is suggestive of ongoing deformation associated with the impact structure, the overall low level of seismicity near the impact structure is indistinguishable from that of the regional coastal plain of Virginia and North Carolina (Sibol et al., 1997).

\section{DISCUSSION AND CONCLUSIONS}

A series of subparallel linear bodies of biofragmental sand exhibiting large-scale, westwarddipping cross-beds formed on offshore shoals created by rotation of slump blocks on the perimeter of the Chesapeake Bay impact structure during the late Pliocene. These bodies intertongue with fine-grained basinal deposits to the west and southwest, and later migrate westward across these basin sediments. The angular stratigraphic relationships within and between upper Cenozoic formations, and the progressive truncation of older deposits toward the impact structure center, attest to continued deformation near the crater outer rim during deposition of the late Tertiary sequence.

The Yorktown large cross-bedded biofragmental sand body and the inclined and truncated strata at Big Bethel pit are inside the crater rim of Poag (1996), whereas the Chuckatuck biofragmental sand body and Yadkin structures are more than $20 \mathrm{~km}$ outside Poag's crater rim. The Chuckatuck and Yadkin structures increase the width of the documented fracture zone of the impact structure to $\sim 65 \mathrm{~km}$ from the center of impact. The outer rims of large impact structures are often quite irregular with extended zones of megablock slumping (e.g., Jansa et al., 1989; Koeberl and Anderson, 1996; Spray, 1997).

The strata in the upper $\sim 150 \mathrm{~m}$ respond to differential movement with draping (Fig. 6) in contrast to the faulting that characterizes deeper strata (Poag, 1997). Faults at shallow depths $(<150 \mathrm{~ms})$ are rare within $10 \mathrm{~km}$ of the outer rim in seismic surveys on the York or James Rivers.
The driving forces from lithostatic loading for megablock slippage and compaction of Exmore Breccia are small. Sediment overburden is generally less than $\sim 300 \mathrm{~m}$. Nevertheless, the structures described here, the thickening of postimpact strata into the crater, and the widespread faulting in Eocene-Miocene sediments over the impact structure (Poag, 1996) suggest that fault slip may be significant.

\section{ACKNOWLEDGMENTS}

We thank Rick Berquist, Scott Bruce, and Nick Coch for providing well logs and helpful discussions, Glen Izett for his suggestions and criticisms, Wylie Poag for supplying precise locations of earlier seismic surveys, and Captain Charles Machen of the R/V Langley for the fall 1996 seismic surveys. Martin Chapman kindly provided the compilation of historic earthquakes. Peter Riddle and Nicole Scott helped produce Figure 6. Christian Koeberl and Michael Williams gave constructive reviews. This work was supported by the Jeffress Trust and National Science Foundation grant OCE-9596034.

\section{REFERENCES CITED}

Jansa, L. F., Pe-Piper, G., Robertson, P. B., and Friedenreich, O., 1989, Montagnais: A submarine impact structure on the Scotian Shelf, eastern Canada: Geological Society of America Bulletin, v. 101, p. $450-463$.

Johnson, G. H., 1972, Geology of the Yorktown, Poquoson West, and Poquoson East quadrangles, Virginia: Virginia Division of Mineral Resources Report of Investigations 30, $57 \mathrm{p}$.

Johnson, G. H., and Coch, N. K., 1969, A coquina facies in the Yorktown Formation near Chuckatuck, Virginia and its geological implications, in $\mathrm{Ab}$ stracts for 1968: Geological Society of America Special Paper 121, p. 448.

Koeberl, C., and Anderson, R. R., 1996, Manson and company: Impact structures in the United States, in Koeberl, C., and Anderson, R. R., eds., The Manson impact structure, Iowa: Anatomy of an impact crater: Geological Society of America Special Paper 302, p. 1-29.

Koeberl, C., Poag, C. W., Reimold, W. U., and Brandt, D., 1996, Impact origin of the Chesapeake Bay structure and the source of the North American tektites: Science, v. 271, p. 1263-1266.

Mansfield, W. C., 1943, Stratigraphy of the Miocene of Virginia and the Miocene and Pliocene of North Carolina, in Gardner, J. A., ed., Mollusca from the Miocene and lower Pliocene of Virginia and North Carolina: U.S. Geology Survey Professional Paper 199-A, p. 1-19.

Morgan, J., Warner, M., Chicxulub Working Group, Brittan, J., Buffler, R., Camargo, A., Christeson, G., Denton, P., Hildebrand, A., Hobbs, R. Macintyre, H., Mackenzie, G., Maguire, P., Marin, L., Nakamura, Y., Pilkington, M., Sharpton, V., Snyder, D., Suarez, G., and Trejo, A., 1997, Size and morphology of the Chicxulub impact crater: Nature, v. 390, p. 472-476.
Perry, E., Marin, L., McClain, J., and Velazquez, G., 1995, Ring of cenotes (sinkholes), northwest Yucatan, Mexico: Its hydrogeologic characteristics and possible association with the Chicxulub impact crater: Geology, v. 23, p. 17-20.

Poag, C. W., 1996, Structural outer rim of the Chesapeake Bay impact crater: Seismic and bore hole evidence: Meteoritics and Planetary Science, v. 31 , p. $218-226$.

Poag, C. W., 1997, The Chesapeake Bay bolide impact: A convulsive event in Atlantic Coastal Plain evolution: Sedimentary Geology, v. 108, p. 45-90.

Poag, C. W., Powars, D. S., Poppe, L. J., and Mixon, R. B., 1994, Meteoroid mayhem in Ole Virginny: Source of the North American tektite strewn field: Geology, v. 22, p. 691-694.

Pope, K. O., Ocampo, A. C., Kinsland, G. L., and Smith, R., 1996, Surface expression of the Chicxulub crater: Geology, v. 24, p. 527-530.

Sibol, M. S., Snoke, J. A., and Mathena, E. C., 1996, Southeastern United States Seismic Network Bulletin no. 30: Blacksburg, Virginia, Seismological Observatory, Virginia Polytechnic Institute and State University, $62 \mathrm{p}$.

Sibol, M. S., Bollinger, G. A., and Chapman, M. C., 1997, Catalog of southeastern United States seismicity compiled from various sources: Blacksburg, Virginia, Seismological Observatory, Virginia Polytechnic Institute and State University (electronic format).

Spray, J. G., 1997, Superfaults: Geology, v. 25, p. $579-582$.

Vaughn, A. W., 1997, Stratigraphic and structural evidence for post-impact deformation of late Tertiary deposits in the outer terrace zone of the Chesapeake Bay impact crater, southeastern Virginia [B.S. thesis]: Williamsburg, Virginia, College of William and Mary, $42 \mathrm{p}$.

Ward, L. W., 1993, The G. D. Harris 1890 manuscript on the stratigraphy of Miocene and Pliocene beds at Yorktown, Virginia: Ithaca, New York, Paleontological Research Institution Special Publication $20,118 \mathrm{p}$.

Ward, L. W., and Blackwelder, B. W., 1980, Stratigraphic revision of upper Miocene and lower Pliocene beds of the Chesapeake Group, middle Atlantic Coastal Plain: U.S. Geological Survey Bulletin 1482-D, $61 \mathrm{p}$.

Manuscript received November 24, 1997

Revised manuscript received February 25, 1998

Manuscript accepted March 17, 1998 